\title{
Dynamic and Dual Effects of Glycated Hemoglobin on Estimated Glomerular Filtration Rate in Type 2 Diabetic Outpatients
}

\author{
Chia-Lin Lee ${ }^{a}$ e $\quad$ Tsai-Chung Lic, d Shih-Yi Lin ${ }^{a} \quad$ Jun-Sing Wang ${ }^{a} \quad$ I-Te Lee \\ Li-Nien Tseng $^{\text {a }}$ Yuh-Min Song ${ }^{a}$ Shang-Feng Tsai ${ }^{b}$ Wayne H-H Sheu ${ }^{a, f, g}$
}

Divisions of ${ }^{a}$ Endocrinology and Metabolism, and ${ }^{b}$ Nephrology, Department of Internal Medicine, Taichung Veterans General Hospital, ' ${ }^{G}$ raduate Institute of Biostatistics, College of Public Health, China Medical University, ${ }^{\mathrm{d} D e p a r t m e n t}$ of Healthcare Administration, College of Health Science, Asia University, and ${ }^{e}$ Department of Public Health, College of Public Health, China Medical University, Taichung, and fSchool of Medicine, National Yang Ming Unversity, and ${ }^{g}$ Colleage of Medicine, National Defense Medical Center, Taipei, Taiwan, ROC

\section{Key Words}

Chronic kidney disease $\cdot$ Diabetes mellitus · Estimated glomerular filtration rate · Glycemic control · Glycated hemoglobin $\cdot \mathrm{HbA}_{1 \mathrm{C}}$

\begin{abstract}
Background: Diabetic nephropathy is the leading cause of incident end-stage renal disease in Taiwan. Previous studies on the consistent benefits of glycemic control in diabetic nephropathy focused primarily on delaying microalbuminuria. However, this effect on glomerular filtration rate (GFR) remains controversial. This study aims to establish a model that explains the controversial effects of glycated hemoglobin $\left(\mathrm{HbA}_{1 \mathrm{C}} \mathrm{C}\right)$ on GFR. Methods: This retrospective cohort study followed subjects with type 2 diabetes mellitus, who were enrolled between June 2006 and December 2006, for 4 years. The effects of $\mathrm{HbA}_{1 \mathrm{C}}$ on estimated GFR (eGFR) were examined both cross-sectionally and longitudinally. The dual effects of $\mathrm{HbA}_{1 \mathrm{C}}$ on eGFR, and how renal function interferes with these effects, were investigated. Results: Of the 1,992 subjects enrolled, 1,699 completed the follow-up. $\mathrm{HbA}_{1 \mathrm{C}}$ was positively correlated with eGFR in the cross-sectional study ( $\beta$ coefficient $=1.44,95 \% \mathrm{Cl}: 0.71-2.17, \mathrm{p}=$ 0.0001 ). In the longitudinal study, higher baseline $\mathrm{HbA}_{1 \mathrm{c}}$ re-
\end{abstract}

\section{KARGER}

(c) 2013 S. Karger AG, Basel

0250-8095/13/0381-0019\$38.00/0

E-Mail karger@karger.com

www.karger.com/ajn sulted in a greater decline in eGFR. The annual eGFR decline rates were $-1.89,-1.29$, and $-0.68 \mathrm{ml} / \mathrm{min} / 1.73 \mathrm{~m}^{2} /$ year for baseline $\mathrm{HbA}_{1 \mathrm{C}}>9,7$ to $\leq 9$, and $\leq 7 \%$, respectively. The eGFR value was simultaneously affected by concurrent ( $\beta$ coefficient $=0.78,95 \% \mathrm{Cl}: 0.48-1.08, \mathrm{p}<0.0001)$ and preceding $\mathrm{HbA}_{1 C}(-0.52,-0.82$ to $-0.23, \mathrm{p}<0.0001)$. The positive effects of concurrent $\mathrm{HbA}_{1 \mathrm{C}}$ on eGFR reached statistical significance at all stages of chronic kidney disease (CKD); however, the negative effects of preceding $\mathrm{HbA}_{1 C}$ only applied to CKD stages 3 and 4. Conclusions: We developed a new model that demonstrates how preceding and concurrent $\mathrm{HbA}_{1 \mathrm{C}} \mathrm{si}-$ multaneously affect eGFR in opposing ways. The dynamic effects varied among different CKD stages. The deterioration in eGFR at CKD stages 3 and 4 may be postponed by intensive glycemic control. Further prospective studies may be necessary to clarify the specific CKD stage(s) that will benefit from intensive glycemic control.

Copyright $\odot 2013$ S. Karger AG, Basel

\section{Introduction}

Diabetic nephropathy is the leading cause of incident end-stage renal disease (ESRD) in Taiwan [1]. The incidence of chronic kidney disease (CKD) increases with in- 
creasing levels of glycated hemoglobin $\left(\mathrm{HbA}_{1 \mathrm{C}}\right)$ [2]. The UK Prospective Diabetes Study (UKPDS) demonstrated that intensive glycemic control decreased the risk of microvascular complications [3].The Diabetes Control and Complications Trial (DCCT) further proved that intensive glycemic control reduced the incidence of microalbuminuria in patients with type 1 diabetes mellitus (DM) [4]. Likewise, in the Action in Diabetes and Vascular Disease: Preterax and Diamicron Modified-Release Controlled Evaluation (ADVANCE) study, intensive glucose control resulted in a reduction in renal events [5]. Although the benefits of glycemic control, such as renal protection, have been widely and consistently reported, previous investigations have primarily focused on delaying the development of microalbuminuria. Intensive diabetic therapy was only recently shown to be associated with a slower reduction in glomerular filtration rate (GFR) than conventional therapy in type $1 \mathrm{DM}$ patients via the longterm follow-up of the Epidemiology of Diabetes Interventions and Complications (EDIC) study [6]. However, the effects of intensive glycemic control on the preservation of GFR in type $2 \mathrm{DM}$ patients remain unclear.

A previous cross-sectional study in early type $1 \mathrm{DM}$ patients demonstrated that $\mathrm{HbA}_{1 \mathrm{C}}$ positively correlated with GFR [7]. This positive correlation existed not only in early type $1 \mathrm{DM}$, but also in type $2 \mathrm{DM}$ patients [8]. Conversely, results from a longitudinal observational study demonstrated that higher baseline $\mathrm{HbA}_{1 \mathrm{C}}$ resulted in a more rapid GFR decline [9]. These seemingly opposing correlations suggest that the actual relationship between $\mathrm{HbA}_{1 \mathrm{C}}$ and GFR cannot be explained by a simple linear model. Additionally, the positive correlation between concurrent $\mathrm{HbA}_{1 \mathrm{C}}$ and GFR also raised the question of how glycemic status alters renal function. Thus far, no literature has provided an ideal model to account for the inconsistent relationship between $\mathrm{HbA}_{1 \mathrm{C}}$ and GFR. To clarify these issues, this study aims to establish a model that explains the controversial effects of $\mathrm{HbA}_{1 \mathrm{C}}$ on GFR via cross-sectional and longitudinal analyses.

\section{Methods}

\section{Study Population}

This retrospective cohort study was performed by physicians at a medical center in central Taiwan. Subjects were recruited from the outpatient department between June 2006 and December 2006 based on a documented diagnosis of type 2 DM by an endocrinologist. Their medical records were reviewed, and their clinical parameters were recorded. The baseline variables assessed included age, sex, $\mathrm{HbA}_{1 \mathrm{C}}$, estimated GFR (eGFR), number of oral antidiabetic drugs (OAD), systolic blood pressure (SBP), and diastolic blood pressure (DBP). Any use of insulin, and antihypertensive and antihyperlipidemic medication during enrollment was also recorded. From 2007 to $2010, \mathrm{HbA}_{1 \mathrm{C}}$ and eGFR were followed up at 12 -month intervals. $\mathrm{HbA}_{1 \mathrm{C}}$ was measured with boronate affinity high-performance liquid chromatography (CLC385 $5^{\mathrm{TM}}$, Primus, Kansas City, Mo., USA). Inter- and intra-assay coefficients of variation for $\mathrm{HbA}_{1 \mathrm{c}}$ (range $4.2-19.6 \%$ ) were $<0.9(0.73)$ and $<2.9 \%$ (1.93\%), respectively. The eGFR was calculated using the modification of diet in renal disease (MDRD) equation: $M D R D=186 \times$ serum creatinine $(\mathrm{mg} / \mathrm{dl})^{-1.154} \times$ years $^{-0.203} \times(0.742$, if female $) \times$ (1.210, if African American). The MDRD formula was chosen over the Cockcroft and Gault formula due to its superior accuracy in diabetic patients with impaired renal function [8]. Although CKDEPI (Epidemiology Collaboration) is more accurate than the MDRD equation for subjects with eGFR $>60 \mathrm{ml} / \mathrm{min} / 1.73 \mathrm{~m}^{2}$, the MDRD formula was applied in the Taiwan National Database to evaluate dialysis initiation and CKD prevalence [10-12]. Subjects whose baseline eGFR was $>180 \mathrm{ml} / \mathrm{min} / 1.73 \mathrm{~m}^{2}$ were excluded. This study was approved by the Human Research Review Committee of the Taichung Veterans General Hospital.

\section{Study Design}

The design of this study was divided into the following sequential parts. First, we examined the positive correlation between $\mathrm{HbA}_{1 \mathrm{C}}$ and eGFR using a cross-sectional analysis. Then, the negative correlation between $\mathrm{HbA}_{1 \mathrm{C}}$ and future GFR values was identified, and the annual eGFR decline was calculated to represent the rate of renal impairment over time. If $\mathrm{HbA}_{1 \mathrm{C}}$ was negatively correlated with future eGFR, then it may be assumed that a higher baseline $\mathrm{HbA}_{1 \mathrm{C}}$ may cause a greater annual eGFR decline in subsequent years. If $\mathrm{HbA}_{1 \mathrm{C}}$ was positively correlated with $\mathrm{eGFR}$ in the cross-sectional analysis but negatively correlated with future eGFR, then it may be deduced that the impact of $\mathrm{HbA}_{1 \mathrm{C}}$ on eGFR varies with time. Lastly, we investigated the possibility that the two opposite effects may coexist, and how renal function status may interfere with these effects.

\section{Statistical Analyses}

Descriptive statistics for continuous variables are expressed as means and standard deviations. All reported $\mathrm{p}$ values were two sided and considered significant when $\mathrm{p}<0.05$. Additionally, $95 \%$ confidence intervals are reported. For the correlation between $\mathrm{HbA}_{1 \mathrm{C}}$ values and eGFR in the cross-sectional analysis, the fixed effect model analysis was used, with baseline eGFR as the dependent variable, to determine the individual related variables with univariate linear regression analysis. The variables that significantly contributed to baseline eGFR in univariate analysis were used in multivariate analysis. Due to the collinearity between age and eGFR, age by decades was used instead. For the effects of $\mathrm{HbA}_{1 \mathrm{C}}$ on future eGFR, we used a mixed model repeated measures (MMRM) to evaluate the eGFR decline rate according to different levels of baseline $\mathrm{HbA}_{1 \mathrm{c}}$. Each eGFR was set as the dependent variable, whereas time was set as the independent variable. Changes in the annual eGFR were defined as the $\beta$ coefficient of time in MMRM. Baseline $\mathrm{HbA}_{1 \mathrm{C}}$ were categorized according to $\mathrm{HbA}_{1 \mathrm{C}}$ $>9 \%, 7 \%<\mathrm{HbA}_{1 \mathrm{C}} \leq 9 \%$, and $\mathrm{HbA}_{1 \mathrm{C}} \leq 7 \%$. Baseline eGFR were categorized according to eGFR $\geq 60$ and $<60 \mathrm{ml} / \mathrm{min} / 1.73 \mathrm{~m}^{2}$. Other variables that were significantly associated with baseline eGFR in multivariate analysis were also entered into MMRM analysis as covariates. Interaction of time, according to $\mathrm{HbA}_{1 \mathrm{C}}$ category, 
Table 1. Baseline characteristics of the study subjects

\begin{tabular}{lc}
\hline Variable & Total $\mathrm{n}=1,992$ \\
\hline Gender, male & $1,067(53.6)$ \\
Mean age, years & $66.1(12.7)$ \\
Mean SBP, $\mathrm{mm} \mathrm{Hg}$ & $132(16.0)$ \\
Mean DBP, mm Hg & $76(9.6)$ \\
Mean HbA $1 \mathrm{C}, \%$ & $8.1(1.82)$ \\
Mean eGFR, ml/min/1.73 m ${ }^{2}$ & $62.1(24.35)$ \\
Number of OAD used & $1.4(0.8)$ \\
$\quad$ 0 OAD & $253(12.7)$ \\
1 OAD & $810(40.7)$ \\
2 OAD & $766(38.5)$ \\
3 OAD & $156(7.8)$ \\
4 OAD & $7(0.4)$ \\
Insulin usage & $374(18.8)$ \\
Hypertensive treatment & $1,486(74.6)$ \\
Hyperlipidemia medication & $663(33.3)$ \\
\hline
\end{tabular}

Values are presented as $\mathrm{n}(\%)$ or means (SD).

eGFR category, and gender, were tested. If the interaction reached statistical significance, stratified analyses were performed. The crude and adjusted MMRM models were reported separately. By the MMRM method, a $\mathrm{HbA}_{1 \mathrm{C}}$ trend was also analyzed for each subject. Each $\mathrm{HbA}_{1 \mathrm{C}}$ was set as the dependent variable, whereas time was set as the independent variable. The $\mathrm{HbA}_{1 \mathrm{C}}$ trend was defined by the $\beta$ coefficient of time. If the impact of $\mathrm{HbA}_{1 \mathrm{C}}$ on eGFR varied with time, we assumed that each eGFR value was simultaneously influenced by concurrent and preceding $\mathrm{HbA}_{1 \mathrm{C}}$. Concurrent $\mathrm{HbA}_{1 \mathrm{C}}$ was defined as the $\mathrm{HbA}_{1 \mathrm{C}}$ value recorded at the same time as the $\mathrm{eGFR}$ value was examined. Preceding $\mathrm{HbA}_{1 \mathrm{C}}$ was defined as the $\mathrm{HbA}_{1 \mathrm{C}}$ recorded 1 year before the eGFR was examined. Preceding eGFR was defined as the eGFR value recorded 1 year before the examined eGFR. Consequently, we constructed another model via MMRM analysis, with eGFR recorded between 2007 and 2010 as the dependent variable. Concurrent and preceding $\mathrm{HbA}_{1 \mathrm{C}}$ were assigned as independent variables. Preceding eGFR, time, and gender were adjusted as covariates. Analyses were also performed separately according to baseline CKD stages. CKD stages $1,2,3,4$, and 5 were defined as baseline eGFR $\geq 90,60-89.99$, $30-59.99,15-29.99$, and $<15 \mathrm{ml} / \mathrm{min} / 1.73 \mathrm{~m}^{2}$, respectively. Statistical analyses were performed using the Statistical Package for Social Sciences (version 15.0; SPSS Inc., Chicago, Ill., USA).

\section{Results}

Of the total 1,992 subjects that were enrolled, 1,699 completed the follow-up. Table 1 summarizes the baseline characteristics of the subjects that were included in the study. Their mean age was 66.1 years, and the mean baseline $\mathrm{HbA}_{1 \mathrm{C}}$ was $8.1 \%$. Over the 4-year follow-up period, the mean $\mathrm{HbA}_{1 \mathrm{C}}$ levels were 8.1, 7.9, 7.7, and 7.7\%
( $\mathrm{p}$ for trend $<0.0001$ ). The mean number of OADs was 1.4. At baseline, $18.8 \%$ of the subjects were on insulin. The mean eGFR at baseline was $62.1 \mathrm{ml} / \mathrm{min} / 1.73 \mathrm{~m}^{2}$, which then decreased to $59.5,57.6,57.9$, and $56.9 \mathrm{ml} / \mathrm{min} / 1.73 \mathrm{~m}^{2}$ in the following 4 years ( $\mathrm{p}$ for trend $<0.0001$ ).

The results of fixed effect model analyses, with eGFR as a dependent variable, are shown in table 2 . In univariate analysis, gender, age (by decade), $\mathrm{HbA}_{1 \mathrm{C}}$, number of $\mathrm{OAD}$, insulin usage, use of antihypertensive medication, SBP, and DBP were associated with baseline eGFR. There was no correlation between hyperlipidemic medication and baseline eGFR. However, due to the possible confounding effects of hyperlipidemic treatment, this variable was also used in multivariate analysis $[13,14]$. In multivariate analysis, the effects of SBP and DBP on baseline eGFR were no longer significant due to collinearity with antihypertensive medications. Meanwhile, age (by decade), number of $\mathrm{OAD}$, and use of antihypertensive medication still correlated with baseline eGFR in multivariate analysis. As expected, baseline $\mathrm{HbA}_{1 \mathrm{C}}$ positively correlated with baseline eGFR, both in univariate and multivariate models. Furthermore, this correlation was still present with the $\mathrm{HbA}_{1 \mathrm{C}}$ and eGFR values for the following years. The adjusted $\beta$ coefficient of $\mathrm{HbA}_{1 \mathrm{C}}$ for eGFR was 1.59 $(\mathrm{p}<0.001), 1.60(\mathrm{p}<0.001), 1.72(\mathrm{p}<0.001)$, and 1.70 $(\mathrm{p}<0.001)$ for years $1,2,3$, and 4 , respectively.

The crude and adjusted annual mean changes in eGFR are presented in table 3 . In regard to the significant interactions, only time by $\mathrm{HbA}_{1 \mathrm{C}}$ and time by eGFR reached statistical significance. However, the difference in the annual mean changes in eGFR between genders did not reach statistical significance $(\mathrm{p}=0.791)$. Stratified analysis was then performed according to the $\mathrm{HbA}_{1 \mathrm{C}}$ and $\mathrm{eGFR}$ categories. The annual mean change in eGFR did differ between the $\mathrm{HbA}_{1 \mathrm{C}}$ and eGFR categories. The adjusted annual decline in eGFR was $-1.90\left(\mathrm{ml} / \mathrm{min} / 1.73 \mathrm{~m}^{2} /\right.$ year $)$, -1.46 , and -0.85 , for baseline $\mathrm{HbA}_{1 \mathrm{C}}>9 \%, 7 \%<\mathrm{HbA}_{1 \mathrm{C}}$ $\leq 9 \%$, and $\mathrm{HbA}_{1 \mathrm{C}} \leq 7 \%$, respectively. The adjusted annual changes in eGFR were -2.56 and $-0.78 \mathrm{ml} / \mathrm{min} / 1.73 \mathrm{~m}^{2} /$ year for baseline eGFR $\geq 60$ and $<60 \mathrm{ml} / \mathrm{min} / 1.73 \mathrm{~m}^{2}$, respectively. Higher baseline $\mathrm{HbA}_{1 \mathrm{C}}$ and eGFR were both associated with more rapid annual eGFR decline. We also used a new category combining both baseline $\mathrm{HbA}_{1 \mathrm{C}}$ and eGFR status. In subjects with baseline eGFR $\geq 60 \mathrm{ml} /$ $\mathrm{min} / 1.73 \mathrm{~m}^{2}$, higher baseline $\mathrm{HbA}_{1 \mathrm{C}}$ was still associated with a greater decline in annual eGFR $(p=0.046)$. In those with baseline eGFR $<60 \mathrm{ml} / \mathrm{min} / 1.73 \mathrm{~m}^{2}$, higher baseline $\mathrm{HbA}_{1 \mathrm{C}}$ still demonstrated a tendency towards a faster eGFR decline, although this did not reach statistical significance $(\mathrm{p}=0.219)$. Furthermore, for the $\mathrm{HbA}_{1 \mathrm{C}}$ trend, 
Table 2. Fixed effect model analyses with eGFR as the dependent variable

\begin{tabular}{|c|c|c|c|c|}
\hline \multirow[t]{2}{*}{ Variable } & \multicolumn{2}{|l|}{ Univariable } & \multicolumn{2}{|c|}{ Multivariable adjustment ${ }^{\mathrm{a}}$} \\
\hline & $\beta$ coefficient & $95 \% \mathrm{CI}$ & $\beta$ coefficient & $95 \% \mathrm{CI}$ \\
\hline $\mathrm{HbA}_{1 \mathrm{C}}$ & 1.75 & $1.04, \quad 2.46$ & 1.44 & 0.71, \\
\hline Male & -3.04 & $-5.36, \quad-0.72$ & -0.48 & $-2.94, \quad 1.98$ \\
\hline Age by decade & -7.24 & $-8.07, \quad-6.40$ & -6.39 & $-7.43,-5.36$ \\
\hline Number of OAD & 4.27 & $2.89, \quad 5.65$ & 2.48 & $0.73, \quad 4.23$ \\
\hline Insulin usage & -9.80 & $-12.68,-6.92$ & -9.43 & $-13.18,-5.68$ \\
\hline Hypertensive treatment & -15.15 & $-17.72,-12.59$ & -8.71 & $-11.67,-5.75$ \\
\hline Hyperlipidemia medication & -1.19 & $-3.61, \quad 1.23$ & -2.36 & $-4.90, \quad 0.17$ \\
\hline SBP, $\mathrm{mm} \mathrm{Hg}$ & -0.11 & $-0.18,-0.03$ & -0.04 & -0.14 \\
\hline $\mathrm{DBP}, \mathrm{mm} \mathrm{Hg}$ & 0.25 & $0.12, \quad 0.37$ & 0.11 & -0.03 \\
\hline
\end{tabular}

${ }^{\text {a }}$ Covariates are shown with a significant contribution to the multivariable model.

Table 3. Crude and adjusted annual mean changes in eGFR

\begin{tabular}{|c|c|c|c|c|c|c|}
\hline $\begin{array}{l}\text { Group/ } \\
\text { subgroup }\end{array}$ & $\begin{array}{l}\text { Patients } \\
\mathrm{n}\end{array}$ & $\begin{array}{l}\text { Crude annual } \\
\text { decline in eGFR }\end{array}$ & $95 \% \mathrm{CI}$ & $\begin{array}{l}\text { Adjusted annual } \\
\text { decline in eGFR }\end{array}$ & $95 \% \mathrm{CI}$ & $\begin{array}{l}\mathrm{p} \text { value for } \\
\text { interaction }\end{array}$ \\
\hline Total & 1,699 & -1.24 & $-1.68,-0.84$ & -1.39 & $-1.74,-1.04$ & \\
\hline Female & 776 & -1.34 & $-1.94,-0.74$ & -1.46 & $-1.98,-0.95$ & \\
\hline \multicolumn{7}{|l|}{ Baseline $\mathrm{Hb}_{1 \mathrm{C}}$} \\
\hline$>9 \%$ & 316 & -1.89 & $-2.92,-0.85$ & -1.90 & $-2.79,-1.01$ & 0.023 \\
\hline$<7 \%$ & 409 & -0.68 & $-1.46, \quad 0.10$ & -0.85 & $-1.55,-0.16$ & \\
\hline Baseline eGFR $>60 \mathrm{ml} / \mathrm{min} / 1.73 \mathrm{~m}^{2}$ & 924 & -2.54 & $-2.93,-2.15$ & -2.56 & $-2.92,-2.19$ & $<0.0001$ \\
\hline \multicolumn{7}{|l|}{$\mathrm{HbA}_{1 \mathrm{C}}$} \\
\hline$>9 \%$ & 188 & -3.39 & $-4.47,-2.31$ & -3.24 & $-4.23,-2.25$ & 0.046 \\
\hline $7-9 \%$ & 341 & -2.34 & $-2.92,-1.76$ & -2.35 & $-2.88,-1.82$ & \\
\hline$<7 \%$ & 217 & -1.92 & $-2.59,-1.24$ & -1.94 & $-2.58,-1.30$ & \\
\hline$<7 \%$ & 192 & -0.16 & $-1.04, \quad 0.71$ & -0.31 & $-1.13, \quad 0.51$ & \\
\hline
\end{tabular}

Adjusted for the number of OAD, insulin usage, hypertensive and hyperlipidemia medication, age (by decade), eGFR and annual eGFR decline (eGFR/year).

we defined $\mathrm{HbA}_{1 \mathrm{C}}$ increasers and decreasers for the $\beta$ coefficient of time $>0$ and $<0$, respectively. $\mathrm{HbA}_{1 \mathrm{C}}$ increasers were with more rapid annual eGFR decline than $\mathrm{HbA}_{1 \mathrm{C}}$ decreasers, although no statistically significant difference was reached (online suppl. material; for all online suppl. material, see www.karger.com/doi/10.1159/000351803). Apart from baseline $\mathrm{HbA}_{1 \mathrm{C}}$ and eGFR category, urinary albumin excretion rate (UAER) also plays an important role in GFR outcome [15]. Supplement 1 also showed the rate of eGFR decline stratified by baseline UAER status. Higher baseline $\mathrm{HbA}_{1 \mathrm{C}}$ still demonstrated a tendency toward a faster annual eGFR decline, especially in patients with macroalbuminuria (UAER $>300 \mathrm{mg} / \mathrm{g}$ creatinine; $\mathrm{p}$ for interaction $=0.025)$. Although the $\mathrm{p}$ value for interaction did not reach significance among normo(UAER $<30 \mathrm{mg} / \mathrm{g}$ creatinine) and microalbuminuria ( $30 \leq$ UAER $\leq 300 \mathrm{mg} / \mathrm{g}$ creatinine), it may be due to the limited sample size. 
$\mathrm{HbA}_{1 \mathrm{C}}$ was found to be positively correlated with eGFR (table 2), but it also induced a further decline in eGFR (table 3). This finding suggests that the impact of $\mathrm{HbA}_{1 \mathrm{C}}$ on eGFR varies at different time points. Table 4 summarizes the dynamic effect of $\mathrm{HbA}_{1 \mathrm{C}}$ on eGFR at different time points, as determined via MMRM. Current $\mathrm{HbA}_{1 \mathrm{C}}$ was found to be positively correlated with eGFR, whereas preceding $\mathrm{HbA}_{1 \mathrm{C}}$ was found to be negatively correlated with eGFR. The dual effects of concurrent and preceding $\mathrm{HbA}_{1 \mathrm{C}}$ on eGFR, according to $\mathrm{CKD}$ stages, are presented in figure 1. Concurrent $\mathrm{HbA}_{1 \mathrm{C}}$ was positively correlated with eGFR at all CKD stages. In contrast, preceding $\mathrm{HbA}_{1 \mathrm{C}}$ was negatively correlated with eGFR in the next year, although differences were only statistically significant at CKD stages 3 and 4. Except CKD stages, different time of preceding $\mathrm{HbA}_{1 \mathrm{C}}$ was further analyzed using a dynamic model. The adjusted $\beta$ coefficient of preceding $\mathrm{HbA}_{1 \mathrm{C}}$ was $-0.52(\mathrm{p}<0.001),-0.51(\mathrm{p}=0.002)$, $-0.54(\mathrm{p}=0.005)$, and $-0.34(\mathrm{p}=0.209)$ for the preceding $1,2,3$, and 4 years (data not shown).

\section{Discussion}

The present study revealed that $\mathrm{HbA}_{1 \mathrm{C}}$ was positively correlated with eGFR via a cross-sectional analysis. A higher baseline $\mathrm{HbA}_{1 \mathrm{C}}$ and higher eGFR resulted in a greater decline in eGFR. Furthermore, preceding $\mathrm{HbA}_{1 \mathrm{C}}$ had a negative effect on eGFR, whereas concurrent $\mathrm{HbA}_{1 \mathrm{C}}$ had a positive effect on eGFR. The dynamic and dual effects of preceding and concurrent $\mathrm{HbA}_{1 \mathrm{C}}$ on eGFR also varied among different $\mathrm{CKD}$ stages.

\section{Cross-Sectional Relationship between $\mathrm{Hb}_{1 \mathrm{C}}$ and eGFR}

Using the fixed effect model, $\mathrm{HbA}_{1 \mathrm{C}}$ was positively correlated with eGFR. Previous studies showed that hyperglycemia increased GFR in subjects with impaired fasting glucose [16]. Similar studies also showed that GFR was significantly correlated with $\mathrm{HbA}_{1 \mathrm{C}}$, both in early type 1 and 2 DM subjects $[7,8]$. Thus, these reports were in accordance with our findings.

\section{Longitudinal Relationship between $\mathrm{Hb}_{1 \mathrm{C}}$ and $e \mathrm{GFR}$}

We demonstrated that a higher baseline $\mathrm{HbA}_{1 \mathrm{C}}$ results in a greater decline in eGFR. This trend was more obvious in those with eGFR $\geq 60 \mathrm{ml} / \mathrm{min} / 1.73 \mathrm{~m}^{2}$ or UAER $>300 \mathrm{mg} / \mathrm{g}$ creatinine. In a longitudinal study on type 1 diabetics with nephropathy, there was a positive correlation between $\mathrm{HbA}_{1 \mathrm{C}}$ and the decline in GFR [17].

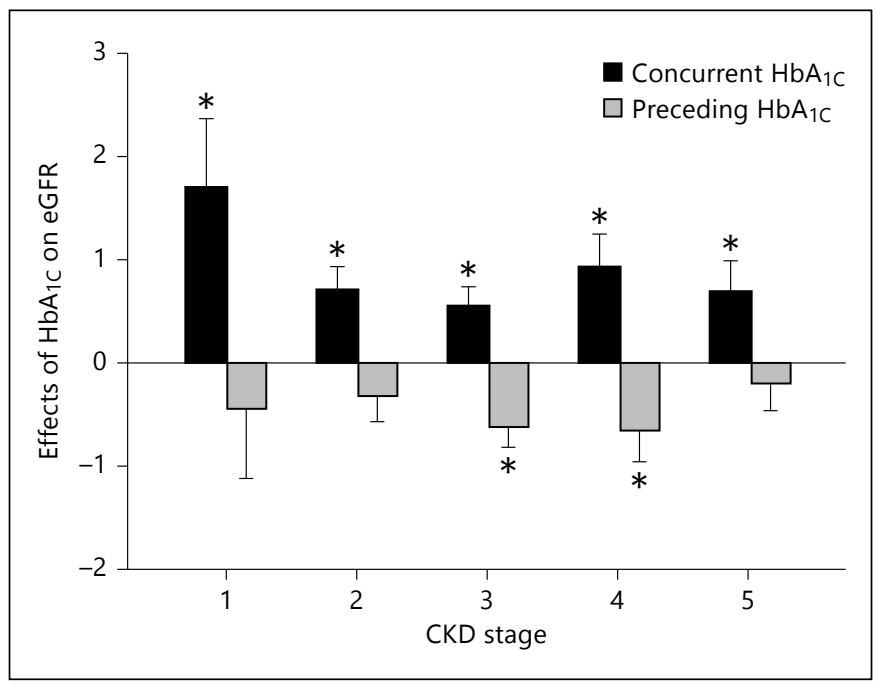

Fig. 1. The dynamic effect of concurrent and preceding $\mathrm{HbA}_{1 \mathrm{C}}$ on current eGFR, according to CKD stage. Current eGFR was estimated using the $\beta$ coefficients of concurrent and preceding $\mathrm{HbA}_{1 \mathrm{C}}$ after adjusting for gender, time, and preceding eGFR. The effects of concurrent and preceding $\mathrm{HbA}_{1 \mathrm{C}}$ on eGFR were opposite. The dependent variable used in the modeling was the annual eGFR value. Separate modeling with MMRM analysis was performed at each CKD stage. Error bars denote the standard error of the $\beta$ coefficients. ${ }^{*}$ p of $\beta$ coefficient $<0.05$.

Table 4. Dynamic impact of concurrent and preceding $\mathrm{HbA}_{1 \mathrm{C}}$ on eGFR

\begin{tabular}{lllllll}
\hline $\begin{array}{l}\text { Grouping } \\
\text { for analysis }\end{array}$ & \multicolumn{2}{l}{ Concurrent $\mathrm{HbA}_{1 \mathrm{C}}$} & & \multicolumn{2}{c}{ Preceding $\mathrm{HbA}_{1 \mathrm{C}}$} \\
\cline { 2 - 3 } \cline { 6 - 7 } & $\beta$ & $95 \% \mathrm{CI}$ & & $\beta$ & $95 \% \mathrm{CI}$ \\
\hline Total & 0.78 & $0.48,1.08$ & & -0.52 & $-0.82,-0.23$ \\
CKD stage 1 & 1.69 & $0.36,3.02$ & & -0.44 & $-1.80,0.90$ \\
CKD stage 2 & 0.70 & $0.21,1.18$ & & -0.33 & $-0.80,0.14$ \\
CKD stage 3 & 0.55 & $0.16,0.93$ & & -0.63 & $-1.01,-0.25$ \\
CKD stage 4 & 0.93 & $0.27,1.58$ & & -0.66 & $-1.26,-0.05$ \\
CKD stage 5 & 0.68 & $0.07,1.29$ & & -0.20 & -0.74, & 0.33 \\
\hline
\end{tabular}

MMRM analyses, with eGFR as the dependent variable, were performed for the total population and at each CKD stage. The impact of concurrent and preceding $\mathrm{HbA}_{1 \mathrm{C}}$ on eGFR were estimated with the $\beta$ coefficient ( $\beta$ ) after adjusting for preceding eGFR, time, and gender.

Additionally, we reported that subjects with baseline eGFR $\geq 60 \mathrm{ml} / \mathrm{min} / 1.73 \mathrm{~m}^{2}$ had greater eGFR decline rates than those with baseline eGFR $<60 \mathrm{ml} / \mathrm{min} / 1.73 \mathrm{~m}^{2}$. Comparable prospective studies in type $2 \mathrm{DM}$ patients indicated that there was a significant relationship be- 
tween baseline GFR and changes in GFR [18]. A previous meta-analysis of type $1 \mathrm{DM}$ patients similarly suggested that those with higher baseline GFR tend to develop diabetic nephropathy [19]. Considering the effects of both baseline $\mathrm{HbA}_{1 \mathrm{C}}$ and eGFR status on eGFR decline, the best way to determine the accurate influence of these on eGFR was to combine the two effects together. Using this new classification, we demonstrated that the rate of eGFR decline had a dose-dependent relationship with baseline $\mathrm{HbA}_{1 \mathrm{C}}$ and eGFR status. Subjects with the most preserved renal function and worst glycemic control presented with the fastest rate of eGFR decline. Those who had the worst renal function, but best glycemic control, presented with the slowest rate of eGFR decline; however, this was not statistically significant. This may be due to the limited size of our study population.

\section{Dynamic Association between $\mathrm{Hb}_{1 \mathrm{C}}$ and $e$ GFR}

To the best of our knowledge, this longitudinal study is the first to examine the dynamic and dual effects of $\mathrm{HbA}_{1 \mathrm{C}}$ on eGFR which reflected true clinical conditions. In our dynamic model, the effects of $\mathrm{HbA}_{1 \mathrm{C}}$ on eGFR rely on the 'tug of war' between concurrent and preceding $\mathrm{HbA}_{1 \mathrm{C}}$. At each CKD stage, concurrent $\mathrm{HbA}_{1 \mathrm{C}}$ had a significantly positive effect on eGFR. Moreover, this positive effect was the most apparent in CKD stage 1 . This is compatible with the glomerular hyperfiltration present in early DM [20]. Conversely, preceding $\mathrm{HbA}_{1 \mathrm{C}}$ had a negative effect on eGFR. Although the negative effects of preceding $\mathrm{HbA}_{1 \mathrm{C}}$ on eGFR were seen at each CKD stage, statistical significance was only apparent at CKD stages 3 and 4 . This finding suggests that poor glycemic control precipitated the deterioration in eGFR in those at CKD stages 3 and 4. It also suggests that intensive glycemic control may effectively postpone the deterioration in eGFR at these two CKD stages. In fact, the negative effects of preceding $\mathrm{HbA}_{1 \mathrm{C}}$ actually surpassed the positive effects of concurrent $\mathrm{HbA}_{1 \mathrm{C}}$ at CKD stage 3 (table 4). Therefore, our findings suggest that CKD stage 3 may be the critical stage for delaying eGFR deterioration with intensive glycemic control.

The dynamic and dual effects of concurrent and preceding $\mathrm{HbA}_{1 \mathrm{C}}$ varied among $\mathrm{CKD}$ stages. This finding also reflects the pathophysiology of DM nephropathy. The significantly positive effects of concurrent $\mathrm{HbA}_{1 \mathrm{C}}$ on eGFR at all CKD stages imply that hyperfiltration existed at each CKD stage, but primarily at stage 1 . It is well known that hyperglycemia increases glomerular hyperfiltration by raising the ultrafiltration coefficient and increasing membrane permeability to small dextrans [21].
Additionally, hyperglycemia causes excess deposition of extracellular proteins, mesangial cell expansion by upregulating growth factors, gradual glomerular sclerosis, and, finally, decreased GFR [22]. The decrease in GFR induced by hyperglycemia through multiple factors is consistent with the negative impact of preceding $\mathrm{HbA}_{1 \mathrm{C}}$ on eGFR in our study. Our findings suggest that hyperglycemia may cause glomerular hyperfiltration during earlier rather than later stages of CKD. At CKD stages 3 and 4, poor glycemic control results in increased deposition of extracellular proteins. Thus, in the later stages of CKD, the negative impact of hyperglycemia on GFR becomes more dominant. At CKD stage 5, when glomerular sclerosis is most severe and little renal function remains, the renalprotective effects of intensive glycemic control become less obvious. The classic five stages of nephropathy were previously described by Mogensen et al. [23]. Microalbuminuria plays an important role in this staging system, and adequate glycemic control reduces the development of microalbuminuria [24]. Our study proposed that, at CKD stages 3 and 4 , there may be another critical point for delaying the progression of DM nephropathy using strict glycemic control.

In the ACCORD (Action to Control Cardiovascular Risk in Diabetes) study, intensive glycemic control did not reveal any improvements in serum creatinine [25]. In the VADT (Veterans Affairs Diabetes Trial), there were no benefits of intensive glycemic control on the rate of GFR decline [26]. In the DCCT study, there were no differences in the slopes of creatinine clearance between intensive and conventional glycemic control [27]. However, in the EDIC study, intensive diabetic therapy resulted in a slower eGFR decline than conventional therapy [6]. In the UKPDS study, intensive glycemic control resulted in a significant reduction in the proportion of doubling serum creatinine [24]. With the exception of differences in age, study population, or follow-up duration, the dynamic and dual effects of $\mathrm{HbA}_{1 \mathrm{C}}$ may offer another explanation for the controversial findings among the abovementioned studies. Since $\mathrm{HbA}_{1 \mathrm{C}}$ at different time points had opposing effects on eGFR, the net effect of $\mathrm{HbA}_{1 \mathrm{C}}$ on eGFR should be the sum of the impact of both preceding and concurrent $\mathrm{HbA}_{1 \mathrm{C}}$. Therefore, certain studies may fail to observe the direct benefits of good glycemic control on improving GFR. Additionally, the opposing dual effects of $\mathrm{HbA}_{1 \mathrm{C}}$ varied among the different CKD stages. This may cause more heterogeneous results among studies if the study populations are not stratified according to the CKD stages. The dynamic model can apply not only to heterogeneous effects among CKD stages, but also to 
the memory effect of $\mathrm{HbA}_{1 \mathrm{C}}$. The negative effects of preceding $\mathrm{HbA}_{1 \mathrm{C}}$ on eGFR reached statistical significance from preceding years $1-3$. In the DCCT trial, $\mathrm{HbA}_{1 \mathrm{c}}$ from preceding years $2-3$ were associated with the greatest relative risk of contributing to current retinopathy [28]. Although studying different diabetic complications, our findings revealed a similar time effect of preceding $\mathrm{HbA}_{1 \mathrm{C}}$ in accordance with the DCCT trial. However, we lack sufficient data to show the effect of $\mathrm{HbA}_{1 \mathrm{C}}$ levels before the preceding 4 years on renal function.

\section{Clinical Implications}

Based on our study findings, we recommend maintaining $\mathrm{HbA}_{1 \mathrm{C}} \leq 7 \%$ for renal protection in type $2 \mathrm{DM}$ subjects. This may transiently decrease the eGFR due to a correction in hyperfiltration, similar to newly diagnosed DM patients [29]. In the long-term, however, proper glycemic control will provide better renal protection by improving the rate of eGFR decline. In our study, $\mathrm{HbA}_{1 \mathrm{C}}$ increasers presented more rapid annual eGFR decline than $\mathrm{HbA}_{1 \mathrm{C}}$ decreasers, though no statistically significant difference was reached. This finding also supports maintaining $\mathrm{HbA}_{1 \mathrm{C}} \leq 7 \%$ for eGFR preservation.

The strengths of this study include recruitment from a clinical practice, a regular longitudinal follow-up, a large sample size, and the new concept of dynamic and dual effects of $\mathrm{HbA}_{1 \mathrm{C}}$ on eGFR. However, the following limita- tions of this study should be mentioned. First, $\mathrm{HbA}_{1 \mathrm{C}}$ variability was not examined in this study, although it was reported as an independent predictor of nephropathy [30]. Second, although we adjusted for baseline covariates that may affect GFR, we did not annually collect all potential covariates, such as variations in blood pressure or changes in medication. This may cause some bias in the estimations. Despite these limitations, different models from cross-sectional, longitudinal, and dynamic analyses revealed a consistent relationship between $\mathrm{HbA}_{1 \mathrm{C}}$ and eGFR. Therefore, we consider our findings robust.

In conclusion, we provided a new model which suggests that preceding and concurrent $\mathrm{HbA}_{1 \mathrm{C}}$ dynamically affect eGFR in opposing ways. The deterioration in eGFR at CKD stages 3 and 4 may be postponed by intensive glycemic control. Further well-designed, prospective studies are needed to further specify the CKD stages that will actually benefit from intensive glycemic control.

\section{Disclosure Statement}

Dr. Wayne H.-H. Sheu received payment for lectures and consultant fees from MSD, Bayer Schering Pharma, Pfizer, Novo Nordisc, Eli Lilly, Astra-Zeneca, Abbott, Takeda and Boehringer Ingelheim, and research funding from Bayer Schering Pharma, Pfizer, Novo Nordisc and MSD. He and his family did not hold stock directly or indirectly in the above-mentioned companies.

\section{References}

1 Wu M-S, Wu I-W, Shih C-P, Hsu K-H: Establishing a platform for battling end-stage renal disease and continuing quality improvement in dialysis therapy in Taiwan - Taiwan Renal Registry Data System (TWRDS). Acta Nephrol 2011;25:148-153.

2 Ritz E: Limitations and future treatment options in type 2 diabetes with renal impairment. Diabetes Care 2011;34(suppl 2):S330-S334.

3 UK Prospective Diabetes Study (UKPDS) Group: Intensive blood-glucose control with sulphonylureas or insulin compared with conventional treatment and risk of complications in patients with type 2 diabetes (UKPDS 33). Lancet 1998;352:837-853.

4 The Diabetes Control and Complications Trial Research Group: The effect of intensive treatment of diabetes on the development and progression of long-term complications in insulin-dependent diabetes mellitus. $\mathrm{N}$ Engl J Med 1993;329:977-986.

5 Poulter NR: Blood pressure and glucose control in subjects with diabetes: new analyses from ADVANCE. J Hypertens Suppl 2009; 27:S3-S8.
6 DCCT/EDIC Research Group, de Boer IH, Sun W, Cleary PA, Lachin JM, Molitch ME, Steffes MW, Zinman B: Intensive diabetes therapy and glomerular filtration rate in type 1 diabetes. N Engl J Med 2011;365:23662376.

7 Soper CP, Barron JL, Hyer SL: Long-term glycaemic control directly correlates with glomerular filtration rate in early type 1 diabetes mellitus before the onset of microalbuminuria. Diabet Med 1998;15:1010-1014.

8 Rigalleau V, Lasseur C, Raffaitin C, Perlemoine C, Barthe N, Chauveau P, Combe C, Gin H: Glucose control influences glomerular filtration rate and its prediction in diabetic subjects. Diabetes Care 2006;29:14911495.

9 Yokoyama H, Kanno S, Takahashi S, Yamada D, Itoh H, Saito K, Sone H, Haneda M: Determinants of decline in glomerular filtration rate in nonproteinuric subjects with or without diabetes and hypertension. Clin J Am Soc Nephrol 2009;4:1432-1440.

10 Teo BW, Xu H, Wang D, Li J, Sinha AK, Shuter B, Sethi S, Lee EJ: GFR estimating equations in a multiethnic Asian population. Am J Kidney Dis 2011;58:56-63.

11 Hsu CC, Hwang SJ, Wen CP, Chang HY, Chen T, Shiu RS, Horng SS, Chang YK, Yang WC: High prevalence and low awareness of CKD in Taiwan: a study on the relationship between serum creatinine and awareness from a nationally representative survey. Am J Kidney Dis 2006;48:727-738.

12 Hwang SJ, Yang WC, Lin MY, Mau LW, Chen HC: Impact of the clinical conditions at dialysis initiation on mortality in incident haemodialysis patients: a national cohort study in Taiwan. Nephrol Dial Transplant 2010;25: 2616-2624.

13 Sandhu S, Wiebe N, Fried LF, Tonelli M: Statins for improving renal outcomes: a metaanalysis. J Am Soc Nephrol 2006; 17:20062016.

14 Strippoli GF, Navaneethan SD, Johnson DW, Perkovic V, Pellegrini F, Nicolucci A, Craig JC: Effects of statins in patients with chronic kidney disease: meta-analysis and meta-regression of randomised controlled trials. BMJ 2008;336:645-651. 
15 Gaede P, Tarnow L, Vedel P, Parving HH, Pedersen O: Remission to normoalbuminuria during multifactorial treatment preserves kidney function in patients with type 2 diabetes and microalbuminuria. Nephrol Dial Transplant 2004;19:2784-2788.

16 Melsom T, Mathisen UD, Ingebretsen OC, Jenssen TG, Njolstad I, Solbu MD, Toft I, Eriksen BO: Impaired fasting glucose is associated with renal hyperfiltration in the general population. Diabetes Care 2011;34:1546-1551.

17 Hovind P, Rossing P, Tarnow L, Smidt UM, Parving HH: Progression of diabetic nephropathy. Kidney Int 2001;59:702-709.

18 Silveiro SP, Friedman R, de Azevedo MJ, Canani LH, Gross JL: Five-year prospective study of glomerular filtration rate and albumin excretion rate in normofiltering and hyperfiltering normoalbuminuric NIDDM patients. Diabetes Care 1996;19:171-174.

19 Magee GM, Bilous RW, Cardwell CR, Hunter SJ, Kee F, Fogarty DG: Is hyperfiltration associated with the future risk of developing diabetic nephropathy? A meta-analysis. Diabetologia 2009;52:691-697.

20 Mogensen CE: Early glomerular hyperfiltration in insulin-dependent diabetics and late nephropathy. Scand J Clin Lab Invest 1986; 46:201-206.
21 Remuzzi A, Viberti G, Ruggenenti P, Battaglia C, Pagni R, Remuzzi G: Glomerular response to hyperglycemia in human diabetic nephropathy. Am J Physiol 1990;259:F545-F552.

22 Lam S, Verhagen NA, Strutz F, van der Pijl JW, Daha MR, van Kooten C: Glucose-induced fibronectin and collagen type III expression in renal fibroblasts can occur independent of TGF-beta1. Kidney Int 2003;63: 878-888.

23 Mogensen CE, Christensen CK, Vittinghus E: The stages in diabetic renal disease. With emphasis on the stage of incipient diabetic nephropathy. Diabetes 1983;32(suppl 2):64-78.

24 Bilous R: Microvascular disease: what does the UKPDS tell us about diabetic nephropathy? Diabet Med 2008;25(suppl 2):25-29.

25 Ismail-Beigi F, Craven T, Banerji MA, Basile J, Calles J, Cohen RM, Cuddihy R, Cushman WC, Genuth S, Grimm RH Jr, Hamilton BP, Hoogwerf B, Karl D, Katz L, Krikorian A, O'Connor P, Pop-Busui R, Schubart U, Simmons $\mathrm{D}$, Taylor $\mathrm{H}$, Thomas A, Weiss $\mathrm{D}$, Hramiak I: Effect of intensive treatment of hyperglycaemia on microvascular outcomes in type 2 diabetes: an analysis of the ACCORD randomised trial. Lancet 2010;376:419-430.
26 Duckworth W, Abraira C, Moritz T, Reda D, Emanuele N, Reaven PD, Zieve FJ, Marks J, Davis SN, Hayward R, Warren SR, Goldman S, McCarren M, Vitek ME, Henderson WG, Huang GD: Glucose control and vascular complications in veterans with type 2 diabetes. N Engl J Med 2009;360:129-139.

27 The Diabetes Control and Complications (DCCT) Research Group: Effect of intensive therapy on the development and progression of diabetic nephropathy in the Diabetes Control and Complications Trial. Kidney Int 1995;47:1703-1720.

28 Lind M, Oden A, Fahlen M, Eliasson B: The shape of the metabolic memory of HbAlc: reanalysing the DCCT with respect to time-dependent effects. Diabetologia 2010;53:10931098.

29 Vora JP, Dolben J, Williams JD, Peters JR, Owens DR: Impact of initial treatment on renal function in newly-diagnosed type 2 (noninsulin-dependent) diabetes mellitus. Diabetologia 1993;36:734-740.

30 Kilpatrick ES, Rigby AS, Atkin SL: A1C variability and the risk of microvascular complications in type 1 diabetes: data from the Diabetes Control and Complications Trial. Diabetes Care 2008;31:2198-2202. 